\title{
Metabolic responses of the hydrothermal vent tube worm Riftia pachyptila to severe hypoxia
}

\author{
Cordelia Arndt $^{1,2, *}$, Doris Schiedek ${ }^{2}$, Horst Felbeck ${ }^{1}$ \\ ${ }^{1}$ University of California San Diego, Scripps Institution of Oceanography, La Jolla, California 92093-0202, USA \\ ${ }^{2}$ Baltic Sea Research Institute at the University of Rostock, Seestrasse 15, D-18119 Rostock-Warnemuende, Germany
}

\begin{abstract}
The metabolic capabilities of the hydrothermal vent tube worm Riftia pachyptila to tolerate short-and long-term exposure to hypoxia were investigated. After incubating specimens under anaerobic conditions the metabolic changes in body fluids and tissues were analyzed over time. The tube worms tolerated anoxic exposure up to $60 \mathrm{~h}$. Prior to hypoxia the dicarboxylic acid, malate, was found in unusually high concentrations in the blood (up to $26 \mathrm{mM}$ ) and tissues (up to $5 \mathrm{\mu mol} \mathrm{g}^{-1}$ fresh wt). During hypoxia, most of the malate was degraded very quickly, while large quantities of succinate accumulated (blood: about $17 \mathrm{mM}$; tissues: about $13 \mu \mathrm{mol} \mathrm{\textrm {g } ^ { - 1 }}$ fresh wt). Volatile, short-chain fatty acids were apparently not excreted under these conditions. The storage compound, glycogen, was mainly found in the trophosome and appears to be utilized only during extended anaerobiosis. The succinate formed during hypoxia does not account for the use of malate and glycogen, which possibly indicates the presence of yet unidentified metabolic end products. Glutamate concentration in the trophosome decreased markedly during hypoxia, presumably due to a reduction in the autotrophic function of the symbionts during hypoxia. In conclusion, $R$. pachyptila is physiologically well adapted to the oxygen fluctuations frequently occurring in the vent habitat.
\end{abstract}

KEY WORDS: Riftia pachyptila - Anaerobic metabolism - Hypoxia Hydrothermal vents

\section{INTRODUCTION}

Life associated with hydrothermal vents is mainly limited to the narrow region where the hot anoxic vent effluent mixes with the oxygenated ocean bottom water (Corliss et al. 1979, Edmond et al. 1982, Jannasch \& Mottl 1985). The environmental conditions in the vent area are extremely unstable and change rapidly. Johnson et al. (1988a) demonstrated that animals living in the vent environment may experience high concentrations of sulfide as well as extreme hypoxia, depending on the vent water flow. Significant changes in the oxygen concentration could be detected around these organisms within a period of seconds as well as over longer periods (Johnson et al. 1988a, b)

This extreme variation in oxygen availability is likely to have an important impact on the energy metabolism of vent animals that, in the long run, must live aerobically. Enzyme activities found in the tissues of vent

•E-mail: coarndt@ucsd.edu organisms indicate that these animals mainly respire aerobically to gain energy from degrading organic food stuff (Hand \& Somero 1983). While other animals can escape from unfavorable conditions, many vent species cannot do so. The vestimentiferan worm Riftia pachyptila, for example, is a sessile tube-dwelling species that has only a limited ability to respond behaviorally to unfavorable changes in its environment. Juvenile tube worms, in particular, might be affected by hypoxic conditions since they frequently settle at the bottom part of the tubes of adult specimen and are, therefore, more exposed to venting waters (authors' pers. obs.).

Riftia pachyptila is, because of its enormous size of up to $1.5 \mathrm{~m}$ length (Jones 1981a), one of the most conspicuous members of the vent community which forms dense clusters around the hypoxic vent effluents. Adult specimens have no digestive system and derive the major part of their nutrition from intracellular sulfideoxidizing bacteria housed in the trophosome tissue (Jones 1981b). The chemoautotrophic symbionts require 
access both to sulfide and to an oxidant in order for carbon fixation to take place. In addition to oxygen, the bacteria are able to respire nitrate and nitrite (Hentschel \& Felbeck 1993). This metabolic pathway could be a great advantage for the symbionts during environmental hypoxia. While oxygen might already be depleted in the habitat because of its rapid reaction with sulfidic vent waters, nitrate could still be available due to its lower reactivity with sulfide (Jannasch \& Mottl 1985). However, $R$ pachyptila itself cannot take advantage of this pathway since nitrate respiration is restricted to symbiotic bacteria and has not been found in the host or any other metazoan animal.

The various responses of invertebrates to environmental hypoxia have been reviewed by different authors (Bryant 1991, Grieshaber et al. 1994). A common response to anoxia is a switch to fermentative pathways in addition to a reduction in metabolic energy demands. In contrast to aerobic respiration, which provides energy via the respiratory chain, metabolism during anoxia must provide energy by means of substrate-linked phosphorylation. Some species produce lactate and opines from the degradation of carbohydrate, which is the most important energy source during hypoxia. Other anaerobic pathways include the fermentative generation of succinate and volatile, short-chain fatty acids. Even with a relatively high energy gain, free-living animals can utilize anaerobiosis only for a restricted time due to their dependence on limited internal glycogen stores.

Previous investigations have suggested a substantial tolerance of Riftia pachyptila to hypoxia, as the worm was shown to survive at least $36 \mathrm{~h}$ without oxygen (Childress et al. 1984). However, the underlying metabolic mechanisms which enable $R$. pachyptila to tolerate periods without oxygen have not been addressed. In the present study we investigated the metabolic pathways of $R$. pachyptila that sustain activity in the absence of oxygen. The questions we asked in our work were: first, which mechanisms are used by $R$. pachyptila to survive extended periods of anoxia; and, second, is the autotrophic functioning of the symbionts of the tube worm affected in any way by oxygen deficiency?

\section{MATERIALS AND METHODS}

Animal collection. Specimens were collected during the 'HOT96' expedition to the hydrothermal vents at $9^{\circ} \mathrm{N}$ and $13^{\circ} \mathrm{N}$ along the East Pacific Rise $(2600 \mathrm{~m}$ depth). The animals were recovered with the submersible 'Nautile' of the NO 'Nadir' (IFREMER, France) in a thermally insulated container. After reaching the surface, the worms were repressurized to 210 atm in a flow-through aquarium system similar to that described in Goffredi et al. (1997). To maintain the specimens in a healthy condition, the flow-through aquaria were kept at $15^{\circ} \mathrm{C}$ and supplied with sea water containing about $2 \mathrm{mM}$ carbon dioxide, $300 \mu \mathrm{M}$ sulfide, $120 \mu \mathrm{M}$ oxygen and $0.4 \mathrm{mM}$ nitrogen ('maintenance condition'). The $\mathrm{pH}$ of the water was kept at $\mathrm{pH} 6.5$ by an automatic $\mathrm{pH}$-controller that pumped $\mathrm{HCl}$ into the mixing column. The concentration of the gases and sulfide were periodically monitored by gas chromatography (Childress et al. 1984).

Experimental procedure. The tube worms were kept for at least $12 \mathrm{~h}$ under maintenance conditions before an experiment started. To investigate responses to severe hypoxia, the conditions in the high pressure aquaria were changed by bubbling nitrogen gas instead of oxygen through the mixing column, which allowed the oxygen concentration to be maintained between 0 and $6 \mu \mathrm{M}$. The total $\mathrm{CO}_{2}$ and sulfide concentrations were maintained as usual. Specimens were incubated for different periods of time $10,6,17,48$ or $60 \mathrm{~h}$ ) under hypoxic conditions. After $60 \mathrm{~h}$, worms were still considered as healthy based on their response to external stimuli and the red color of their plumes, which turn grayish-slimy in dying specimens.

To investigate whether Riftia pachyptila excretes volatile, short-chain fatty acids, 3 specimens were incubated in hypoxic sea water in heat-sealed polyethylene bags (about $250 \mu \mathrm{m}$ thick) for $12 \mathrm{~h}$. At the end of the experiment, the incubation water from the bags was sampled, adjusted to an alkaline $\mathrm{pH}$ and stored frozen. The fatty acids were later removed by steam distillation according to Kluytmans et al. (1975) and their concentrations determined with a Hewlett Packard gas chromatograph equipped with a flame ionization detector. The column used was a $6 \mathrm{ft}$ (ca $1.8 \mathrm{~m}$ ) long glass column (Supelco) filled with $10 \% \mathrm{SP}$ 1200 and $1 \% \mathrm{H}_{3} \mathrm{PO}_{4}$ on 80/100 Chromosorb WAW

At the end of an incubation period, the worms were removed from the experimental chamber and immediately dissected. Blood was collected from the main ventral and dorsal vessel as well as from the coelomic cavity. Plume, body wall, vostimentum, and trophosome were rinsed, blotted dry and freeze-clamped in liquid nitrogen. All samples were stored at $-80^{\circ} \mathrm{C}$ before extraction. For the immediate analysis on board, the tissues were weighed on a motion compensated ship-board balance system (Childress \& Mickel $1980)$.

Enzyme activities and metabolite determination. The activities of lactate dehydrogenase, octopine dehydrogenase, alanopine dehydrogenase, and strombine dehydrogenase were determined spectrophotometrically in crude homogenates of plume, vestimentum, trophosome, and body wall tissue of freshiy 
caught worms according to Schiedek (1997). The assay temperature was chosen as $25^{\circ} \mathrm{C}$ in order to be comparable to most other published data.

To analyse the concentrations of metabolites indicative of anaerobiosis in the tissues and body fluids of Riftia pachyptila, neutralized perchloric acid extracts were prepared according to Schiedek \& Schoettler (1990). The extraction and hydrolysis of glycogen was performed according to Schoettler (1978). Standard enzymatic methods were employed for measuring glucose, malate, and D- and L-lactate (Bergmeyer 1985). Succinate was determined according to Michal et al. (1976). The separation and detection of free amino acids was performed via HPLC after Schiedek (1997).

To detect changes of the metabolite concentrations during the incubations, the results of different incubation periods were compared to the initial values using a 2 -tailed $t$-test for unpaired results. If $\mathrm{p}$ was smaller than 0.05 , the change was considered significant.

\section{RESULTS}

\section{Accumulation of anaerobic metabolites}

The dicarboxylic acid succinate was found in very high concentrations in the blood (about $7 \mathrm{mM}$ ) and tissues of Riftia pachyptila ( 3 to $10 \mu^{m o l ~ g^{-1}}$ fresh wt) even under aerobic conditions. However, exposure to severe hypoxia raised the succinate levels in all body compartments of the tube worm. After $6 \mathrm{~h}$ without oxygen, the succinate level in the body fluids increased by about $17 \mathrm{mM}$ (Fig. 1a). No significant further accumulation could be detected during longer anoxic incubation periods. The succinate concentration was in the same range in the ventral and dorsal blood and in the coelomic fluid. Succinate accumulated in the tissues throughout the anoxic incubation time (Fig 1b), increasing in both the body wall and the vestimentum from about $3 \mu \mathrm{mol} \mathrm{g}^{-1}$ fresh wt to $16 \mu \mathrm{mol} \mathrm{g}^{-1}$ fresh wt within $60 \mathrm{~h}$. Under hypoxia, the trophosome showed no significant changes in the succinate concentration, while succinate in the plume tissue increased by about $4 \mu \mathrm{mol} \mathrm{g}^{-1}$ fresh wt from 6 to $48 \mathrm{~h}$.
No accumulation of volatile fatty acids was found in the incubation water of Riftia pachyptila. None of the free amino acids tested in the tissues and body fluids of $R$. pachyptila increased significantly during hypoxia. Compared to other amino acids, alanine concentration was very high in the body wall tissue and had a far lower level in other tissues (Table 1). However, no significant hypoxia-related changes could be detected.

\section{Degradation of storage compounds during severe hypoxia}

Malate concentrations decreased rapidly in the blood and tissues during oxygen deficiency (Fig. 2a). Under aerobic maintenance conditions up to $26 \mathrm{mM}$ malate could be detected in the blood. After $6 \mathrm{~h}$ of anaerobic exposure, malate concentration was reduced to about $2 \mathrm{mM}$ in the vascular blood as well as in the

Table 1. Riftia pachyptila. Changes in concentration of the amino acids aspartate and alanine during anaerobiosis in different tissues. Numbers indicate mean values \pm standard deviation. Values in parentheses are numbers of specimens analysed. $\mathrm{n}=4$ for all 6 and $48 \mathrm{~h}$ incubations. $\mathrm{nd}=$ not determined

\begin{tabular}{|c|c|c|c|c|}
\hline \multirow{2}{*}{$\begin{array}{l}\text { Amino acid } \\
\left(\mu \mathrm{mol} g^{-1} \text { fresh } w t\right)\end{array}$} & \multirow{2}{*}{ Tissue } & \multicolumn{3}{|c|}{ Time of anaerobic exposure (h) } \\
\hline & & 0 & 6 & 48 \\
\hline \multirow{4}{*}{ Aspartate } & Plume & nd & $0.2 \pm 0.4$ & 0 \\
\hline & Vestimentum & $1.6 \pm 0.9(6)$ & 0 & 0 \\
\hline & Body wall & $2.2 \pm 0.7 \quad(6)$ & 0 & $0.3 \pm 0.5$ \\
\hline & Trophosome & $3.1 \pm 2.6(10)$ & $7.3 \pm 1.0$ & $2.7 \pm 1.1$ \\
\hline \multirow[t]{4}{*}{ Alanine } & Plume & nd & $3.1 \pm 1.2$ & $3.2 \pm 0.5$ \\
\hline & Vestimentum & $20.2 \pm 6.1 \quad(6)$ & $40.1 \pm 7.6$ & $28.1 \pm 6.9$ \\
\hline & Body wall & $82.0 \pm 8.0 \quad(6)$ & $80.8 \pm 11.2$ & $74.3 \pm 11.2$ \\
\hline & Trophosome & $6.4 \pm 1.8(10)$ & $4.5 \pm 0.8$ & $5.0 \pm 2.0$ \\
\hline
\end{tabular}



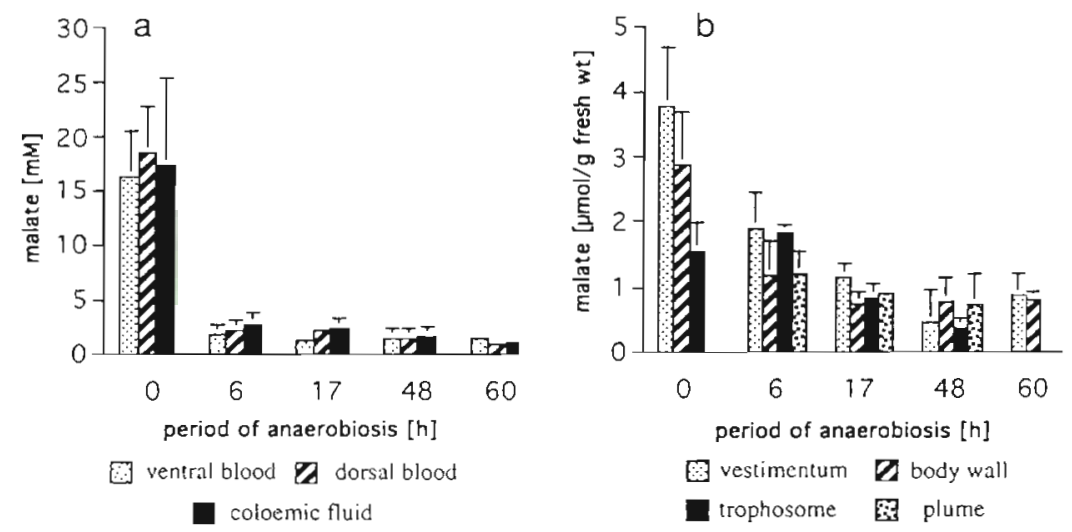

Fig. 2. Riftia pachyptila. Malate concentrations in (a) body fluids and (b) tissues after exposure to anaerobic conditions. Bars represent the mean values $\pm \mathrm{SD}$. $\mathrm{n}=3(0 \mathrm{~h}), 4(6 \mathrm{~h}), 5(17 \mathrm{~h}), 9(48 \mathrm{~h}), 4(60 \mathrm{~h})$. When no bars are shown, no samples were available. The concentrations in the body fluids, body wall, and vestimentum decreased significantly during the first $6 \mathrm{~h}(\mathrm{p}<0.05)$

coelomic fluid. In the tissues of Riftia pachyptila, the malate level was highest in the vestimentum (about $4 \mu \mathrm{mol} \mathrm{g}^{-1}$ fresh $\mathrm{wt}$ ), while the other tissues had lower concentrations (Fig. 2b). A significant reduction in malate content could be found after $6 \mathrm{~h}$ of anaerobic exposure in the body wall and vestimentum of $R$. pachyptila

Glycogen was abundant in the trophosome tissue (about $100 \mu \mathrm{mol}$ glycosyl units $\mathrm{g}^{-1}$ fresh wt), but less concentrated in the remaining body tissues, which contained 17 to $35 \mu \mathrm{mol}$ glycosyl units $\mathrm{g}^{-1}$ fresh wt (Fig. 3). Within the first $17 \mathrm{~h}$ of hypoxia, a significant degradation of glycogen could not be detected in any of the tissues of the tube worm. After $48 \mathrm{~h}$, glycogen store in the trophosome tissue had decreased significantly by about $60 \mu \mathrm{mol}$ glycosyl units $\mathrm{g}^{-1}$ fresh wt. The

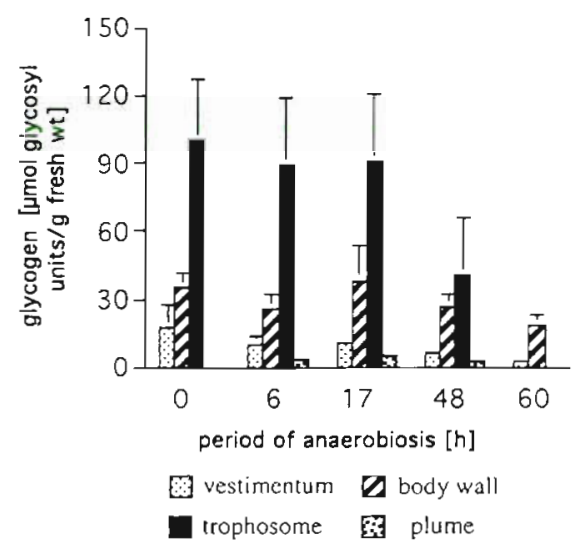

Fig. 3. Riftia pachyptila. Glycogen concentrations in trophosome, body wall, plume, and vestimentum after exposure to anaerobic conditions. Bars represent the mean values $\pm S D$. $\mathrm{n}=3(0 \mathrm{~h}), 4(6 \mathrm{~h}), 5(17 \mathrm{~h}), 9(48 \mathrm{~h}), 4(60 \mathrm{~h})$. When no bars are shown, no samples were available. The concentration in the trophosome decreased significantly after 48 h $(p<0.05)$ utilization of glycogen in both the body wall and vestimentum was much less than in the trophosome even after $60 \mathrm{~h}$ of hypoxia, when it decreased significantly by about 17 and $14 \mu \mathrm{mol}$ glycosyl units $\mathrm{g}^{-1}$ fresh wt, respectively. The glycogen concentration of the plume tissue was very low and decreased only minimally during hypoxia.

Aspartate, which was present in the tissues of Riftia pachyptila in very low concentrations (Table 1), was completely depleted within $6 \mathrm{~h}$ of anaerobic exposure. Glutamate was found in high quantities in the trophosome tissue (Fig. 4). Its concentration declined continuously over the anaerobic incubation period, showing a significant reduction after $48 \mathrm{~h}$.

\section{Enzyme activities}

Octopine dehydrogenase, alanopine dehydrogenase and strombine dehydrogenase activities were not found in any of the samples. Lactate dehydrogenase could be detected in moderate activities both in vestimentum and body wall $\left(4 \mu \mathrm{mol} \mathrm{g}^{-1}\right.$ fresh $\mathrm{wt} \mathrm{min}^{-1}$ and $3 \mu \mathrm{mol} \mathrm{g}{ }^{-1}$ fresh wt $\mathrm{min}^{-1}$, respectively).

\section{DISCUSSION}

When incubating Riftia pachyptila for different periods of severe hypoxia, the tube worms were found in good shape even after $60 \mathrm{~h}$ of anaerobic exposure. All specimens were still actively responding to tactile stimuli and their plumes had a fresh red color as is

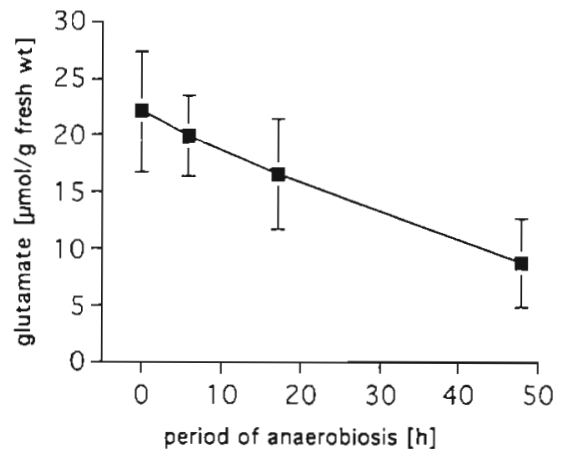

Fig. 4. Riftia pachyptila. Gilutamate concentrations in the trophosome after exposure to anaerobic conditions. The mean values \pm SD are plotted. $n=3(0 \mathrm{~h}), 4(6 \mathrm{~h}), 5(17 \mathrm{~h}), 9(48 \mathrm{~h})$, $4(60 \mathrm{~h})$. The concentration decreased significantly after $48 \mathrm{~h}$ $(\mathrm{p}<0.05)$ 
typical of healthy specimens. However, after $60 \mathrm{~h}$ of hypoxia, in contrast to shorter incubation periods, the plumes of all specimen were retracted into their tubes in the incubation vessels. Since severely stressed $R$. pachyptila are often found with plumes withdrawn into their tubes, this could indicate that the health of the specimens had begun to deteriorate due to their having reached maximal anaerobic tolerance.

An analysis of different body compartments of Riftia pachyptila suggests a significant role of succinate in the anaerobic metabolism of the tube worm. This result is not surprising considering the physiological responses of other marine invertebrates experiencing anoxia. For most invertebrate species investigated, succinate accumulation in the body fluids and tissues is a characteristic feature of their anaerobic metabolic response. Succinate usually originates from aspartate in early stages of anoxia, while glycogen is utilized during extended anaerobiosis to generate energy (adenosine triphosphate, ATP) via substrate phosphorylation (Bryant 1991)

Succinate metabolism in Riftia pachyptila appears to differ from that of other animals. Unusually high concentrations of succinate were found in the body fluids and tissues of the tube worm even under aerobic conditions (Fig.1), whereas other terrestrial, fresh water, and marine species examined display succinate concentrations below $0.1 \mu \mathrm{mol} \mathrm{g}^{-1}$ fresh wt in their tissues (Grieshaber et al. 1994). The normal level found in the tissues of $R$. pachyptila was 30 to 50 times higher (up to $5 \mu \mathrm{mol} \mathrm{g}^{-1}$ fresh wt). Succinate is even more concentrated in the body fluids of the tube worm. Compared to the level of $0.1 \mathrm{mM}$ in the coelomic fluid of the lugworm Arenicola marina (Schoettler \& Bennett 1991), the succinate concentrations in this compartment and in the vascular blood of $R$. pachyptila are about 70 times higher.

The elevated succinate level in the tube worm might suggest that the function of succinate is that of a $\mathrm{CO}_{2}$ carrier. Felbeck (1985) showed that $\mathrm{CO}_{2}$ from the environment is incorporated into the $\mathrm{C}$-4 organic acids malate and succinate after entering the blood via the plume. The author states that succinate is mainly delivered to the chemoautotrophic bacteria in the trophosome, where it can be decarboxylated after conversion to malate. However, it may also be directly utilized by other tissues of Riftia pachyptila. An alternative explanation for the high succinate levels in the tissues might be that the tube worms rely partially on anaerobic metabolic processes even under aerobic conditions. The unusual oxygen binding properties of the blood of R. pachyptila (Arp \& Childress 1981) would seem to support this possibility. Both the vascular and the coelomic hemoglobin have extremely high affinities for oxygen, which could cause very low concentrations of free oxygen inside the tissues of $R$. pachyptila (Fisher et al. 1989, Hentschel \& Felbeck 1993). In addition to hypoxic conditions, the elevated $\mathrm{CO}_{2}$-concentrations in the blood of the tube worm (Childress et al. 1993) may affect the succinate concentration. This metabolic response has been discussed for parasitic helminths which form succinate under aerobic conditions, even though they are able to gain energy aerobically (Barrett 1976). It is believed that the production of organic acids may avoid the problem of tissue acidification which is caused by the high $\mathrm{CO}_{2}$ levels frequently found in the tissues of the terrestrial host animals of helminths (Podesta et al. 1976). A third explanation for the high succinate levels could be that the chemoautotrophic bacteria of $R$. pachyptila excrete succinate as a metabolic product (Felbeck \& Jarchow 1998) which is then transferred to the host.

The large and rapid accumulation of succinate under hypoxic conditions demonstrates the importance of this fermentative process for Riftia pachyptila (Fig. 1). Under anaerobic conditions, succinate formation from glucose results in a larger energy yield compared to lactate fermentation or other dehydrogenase reactions such as opine formation. Instead of $2 \mathrm{~mol} \mathrm{ATP}$ per glycosyl residue, twice as much is generated by succinate production. The metabolic source of the extremely high succinate content after hypoxic exposure of $R$. pachyptila (body fluids: up to $46 \mathrm{mM}$; tissues: up to $23 \mu \mathrm{mol} \mathrm{g} \mathrm{g}^{-1}$ fresh wt) is unknown. Glycogen, a common storage compound, was most concentrated in the trophosome tissue, reaching values of up to $157 \mu \mathrm{mol}$ glycosyl units $\mathrm{g}^{-1}$ fresh wt (Fig. 3). Its depletion, although demonstrable, cannot account for the production of succinate during the initial phases of anaerobic exposure, because a significant degradation of glycogen could only be detected after $48 \mathrm{~h}$. Therefore, a further carbon source for the generation of succinate must be available.

Aspartate is degraded during early anaerobiosis in many marine animals. Its breakdown is responsible for the accumulation of succinate during early stages of anoxia and results in an increase of the alanine concentration due to a transamination reaction (Zebe 1975. Collicutt \& Hochachka 1977, Felbeck 1980). However, since the concentration of aspartate is very low in Riftia pachyptila, it appears to play only a negligible role in the formation of succinate. Only about $2 \mu \mathrm{mol} \mathrm{g}{ }^{-1}$ fresh wt could be measured in both the body wall and vestimentum under aerobic conditions (Table 1). Even if these amounts are depleted after $6 \mathrm{~h}$ of anoxia and, possibly, metabolized to succinate and alanine, they cannot account for the extent of succinate production

The analysis of the malate concentrations provides insight into the anaerobic succinate generation in Riftia 
pachyptila. Malate, formed by glycogen depletion, is known as an important intermediate in the anaerobic metabolism of invertebrates, serving as a substrate for mitochondrial energy conversion (Bryant 1991). Under hypoxia, it is oxidized (clockwise) as well as reduced (counterclockwise) in the mitochondrial tricarboxylic acid cycle and leads to the formation of succinate and the short-chain fatty acids acetate and propionate. Previous investigations on $R$. pachyptila showed high concentrations of malate (about $5 \mathrm{mM}$ ) in the coelomic fluid and the blood of freshly recovered tube worms (Felbeck unpubl. data). Our data display even higher malate concentrations of up to $26 \mathrm{mM}$ in the body fluids of worms exposed to aerobic maintenance conditions for at least $12 \mathrm{~h}$. To our knowledge, these numbers are among the highest ever detected in any invertebrate species. The tissues of $R$. pachyptila also display elevated malate concentrations of up to $5 \mu \mathrm{mol}$ $\mathrm{g}^{-1}$ fresh wt.

Previous investigations on annelids have given some insight concerning the metabolism of malate during anoxia. Relatively high concentrations were found in the blood and tissues of Lumbriculus variegatus and Hirudo medicinalis (Zebe et al. 1981, Putzer 1985). Malate was almost completely catabolized in the first hours of anoxia in both species, while similar quantities of succinate accumulated. Our data suggest a similar metabolic mechanism in Riftia pachyptila. Malate, presumably formed in the plume tissue as a $\mathrm{CO}_{2}$-carrier (Felbeck 1985, Felbeck \& Turner 1995), might also serve as an energy source for anaerobic metabolic processes. Under aerobic conditions, malate is decarboxylated in the trophosome tissue to supply the chemoautotrophic bacteria with $\mathrm{CO}_{2}$ (in addition to $\mathrm{CO}_{2}$ dissolved in the blood). Under these circumstances, the bacterial sulfide oxidation generates enough energy to support autotrophic $\mathrm{CO}_{2}$-fixation. During hypoxia, in contrast, the bacterial energy production and, therefore, the autotrophic function of the symbionts, appears to be restricted. This makes it likely that the symbionts fix $\mathrm{CO}_{2}$ less readily under anaerobic conditions than they do under aerobic conditions. Indeed, a decrease of $\mathrm{CO}_{2}$-uptake in intact $R$. pachyptila under anaerobic conditions was observed (Childress pers. comm.) Since the malate stores cannot be rebuilt under these conditions, this might be a cause for the rapid and almost complete utilisation of these reserves.

The only alternative to the oxidation of sulfide with oxygen would be the use of nitrate as an oxidant. As the results of Pospesel et al. (in press) show, nitrate concentrations in the blood of Riftia pachyptila may be up to 100 times the level in ambient sea water. Nitrite, a product of nitrate respiration, was also conspicuously elevated. However, because the energy output from sulfide oxidation by nitrate is lower than via oxygen (Stewart 1988), the bacteria could produce only relatively little ATP and, therefore, could incorporate less $\mathrm{CO}_{2}$. An indication for the declining autotrophic function of the bacteria may be the decrease of free glutamate in the trophosome tissue of $R$. pachyptila under anoxic conditions (Fig. 4). Glutamate was identified as one of the bacterial metabolic products excreted after $\mathrm{CO}_{2}$-fixation (Felbeck \& Jarchow in press). Thus, a decline of its concentration during anoxia could possibly be caused by a reduced generation due to the limited $\mathrm{CO}_{2}$-supply.

While malate appears to be the major anaerobic substrate in Riftia pachyptila during early anaerobiosis, most of the glycogen is used only during extended anoxia. The extent of energy reserve mobilization is more evident if one calculates the sum of substrates mobilized during anoxia in all body compartments of the tube worm and compares it to the sum of anaerobic products accumulating (Table 2). A specimen of $R$. pachyptila of $100 \mathrm{~g}$ fresh wt would degrade about $1400 \mu \mathrm{mol}$ substrate during the first $6 \mathrm{~h}$ of anoxia, while an additional $1600 \mu \mathrm{mol}$ is used up to the end of the $48 \mathrm{~h}$ incubation period. The anaerobic products identified in this study accumulating in the same individual add up to only $900 \mu \mathrm{mol}$ after $6 \mathrm{~h}$ and up to only an additional $400 \mu \mathrm{mol}$ within the following $42 \mathrm{~h}$ of experimental anoxia. It is, therefore, likely that still unidentified anaerobic end products result from the long-term degradation of glycogen.

While many marine invertebrates display high enzyme activities responsible for the reaction of pyruvate with free tissue amino acids in order to produce

Table 2. Riftia pachyptila. Molar balance of substrates and products during anaerobic metabolism calculated for a $100 \mathrm{~g}$ specimen. Numbers represent the sum of identified anaerobic substrates and products utilized or accumulated after 6 and $48 \mathrm{~h}$ of anoxia in all body compartments of the tubeworm. The weight distribution among the individual tissues was: body fluids, about $40 \%$ (Felbeck pers. obs.); plume, $16 \pm 3 \%$; vestimentum, $14 \pm 2 \%$; body wall, $10 \pm 2 \%$; trophosome, $15 \pm 2 \%$ ( $\mathrm{n}=9$ for the latter numbers). The utilization of glycogen is calculated for 0.5 glycosyl units

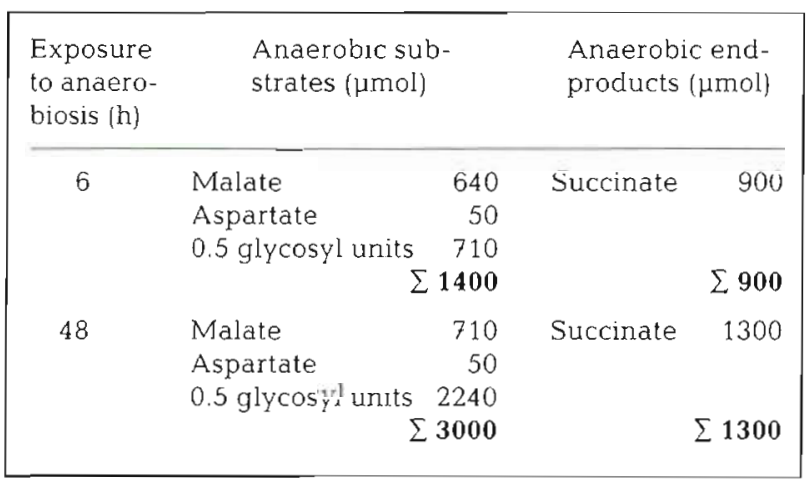


opines, no alanopine, strombine or octopine dehydrogenase could be detected in the tissues of Riftia pachyptila. We could detect low activities of lactate dehydrogenase in body wall and vestimentum of $R$ pachyptila (about 4 and $3 \mu \mathrm{mol} \mathrm{g}^{-1}$ fresh wt $\mathrm{min}^{-1}$, respectively). Lactate dehydrogenase activities in the trophosome were also found by Hand \& Somero (1983). However, only traces of L-lactate $\left(<0.1 \mu \mathrm{mol} \mathrm{g}{ }^{-1}\right.$ fresh wt) and no $D$-lactate could be measured in any body compartments of the tube worm even after $48 \mathrm{~h}$ of anaerobic exposure.

Other fermentation products known to be accumulated and excreted in marine invertebrates under anaerobic conditions are volatile fatty acids such as propionate and acetate. We were not able to detect these compounds in the anaerobic incubation water of Riftia pachyptila. However, we cannot exclude their production. It was not possible to test whether the material of the incubation bags (about $250 \mu$ thick polyethylene) was completely impermeable to shortchain fatty acids. Technical data were not available from the literature. Any permeability would have resulted in a partial loss of fatty acids from the incubation bags. Further experiments are necessary before a definitive statement about the significance of this anaerobic end product of $R$. pachyptila can be made.

Other adaptations to short-term anoxia were found by Childress et al. (1984), who reported oxygen consumption rates in Riftia pachyptila regulated down to low oxygen partial pressures $\left(\mathrm{pO}_{2}\right)$. The authors calculated that the tube worm must be able to maintain its aerobic metabolism under anoxia for about $0.56 \mathrm{~h}$ if their oxygen stores in the blood are saturated. These metabolic properties may help $R$. pachyptila to sustain aerobic functioning during periods of withdrawal into the tube, which is the only way to protect themselves from predators. Whether high-energy phosphagens are also involved in a fast energy provision under anoxia remains to be investigated.

In conclusion, Riftia pachyptila is physiologically well adapted to survive the short-term oxygen fluctuations which are known to occur in the vent habitat. While the malate stores in the blood of the tube worms provide a readily available source which can be drawn upon to generate energy anaerobically, the glycogen in the trophosome may be used during extended periods of hypoxia. However, long-lasting hypoxia could cause problems for the symbiotic association, particularly in juvenile specimens of $R$. pachyptila, which appear to be more exposed to hypoxic vent waters (authors' pers, obs.). Since autotrophic $\mathrm{CO}_{2}$ uptake is restricted during anoxia, the carbon source for a continued supply of organics is unclear. In addition, the recovery mechanisms of this autotrophic system should be further investigated. Because of the limited supply of organic carbon, it appears doubtful whether any metabolic products still capable of producing energy are excreted into the environment. Instead, they are probably recycled internally using the metabolic capabilities of the bacteria.

Acknowledgements. This research was supported by the National Science Foundation grant OCE 93-14525 to H.F., a European Union grant (TMR-LSF: MAST3-CT95-0040) to C.A. and a BMBF grant (DYSMON 03F0123E) to D.S. and C.A. We thank the captains and the crew of the RV 'Wecoma' (USA), NO 'Nadir' and the submersible 'Nautile' (IFREMER, France). Special thanks are due to Ute Hentschel for helpful comments and critical reading of the manuscript.

\section{LITERATURE CITED}

Arp AJ, Childress JJ (1981) Blood function in the hydrothermal vent tube worm. Science 213:342-344

Barrett J (1976) Bioenergetics in helminths. In: van den Bosche $\mathrm{H}$ (ed) Biochemistry of parasites and host-parasite relationships. Elsevier, Amsterdam, p 67-77

Bergmeyer U (1985) Methods of enzymatic analysis, 3rd edn. Vol VII. VCH, Weinheim

Bryant C (1991) Metazoan life without oxygen. Chapman and Hall, London

Childress JJ, Arp AJ, Fisher CR Jr (1984) Metabolic and blood characteristics of the hydrothermal vent tube worm Riftia pachyptila. Mar Biol 83:109-124

Childress JJ, Lee RW, Sanders NK, Felbeck H, Oros D, Toulmond A, Desbruyeres D, Kennicutt MC II, Brooks J (1993) Inorganic carbon uptake in hydrothermal vent tube worms facilitated by high environmental $\mathrm{pCO}_{2}$. Nature $362: 147-149$

Childress JJ, Mickel TJ (1980) A motion compensated shipboard precision balance system. Deep-Sea Res 27A: $965-970$

Collicutt JM, Hochachka PW (1977) The anaerobic oyster heart: coupling of glucose and aspartate fermentation. J Comp Physiol 115:147-157

Corliss JB, Dymond J, Gordon LI, Edmond JM, Herzen RPV, Ballard RD, Green K. Williams D, Bainbridge A, Crane K, van Abel TH (1979) Submarine thermal springs on the Galapagos Rift. Science 203:1073-1083

Edmond JM, Measures C, McDuff RE, Measures Cl (1982) Chemistry of hot springs on the East Pacific Rise and their effluent dispursal. Nature 297:187-191

Felbeck H (1980) Investigations on the role of the amino acids in anaerobic metabolism of the lugworm Arenicola marina L. J Comp Physiol 137:183-192

Felbeck $\mathrm{H}$ (1985) $\mathrm{CO}_{2}$-fixation in the hydrothermal vent lube worm Riftia pachyptila (Jones). Physiol Zool 53:272-281

Felbeck H, Jarchow J (1998) Carbon release from purified chemoautotrophic bactenal symbionts of the hydrothermal vent tube worm Riftia pachyptila. Physiol Zool 71: $294-302$

Felbeck H, Turner PJ (1995) $\mathrm{CO}_{2}$-transport in catheterized hydrothermal vent tube worms, Riftia pachyptila (Jones). J Exp Zool 272:95-102

Fisher CR, Childress JJ, Minnich E (1989) Autotrophic carbon fixation by the chemoautotrophic symbionts of Riftia pachyptila. Biol Bull (Woods Hole) 177:372-385

Goffredi SK, Childress JJ, Desaulniers NK, Lee RW, Lallier $\mathrm{FH}$, Hammond D (1997) Inorganic carbon aquisition by the 
hydrothermal vent tube worm Riftia pachyptila depends upon high external $\mathrm{pCO}_{2}$ and upon proton-equivalent ion transport by the worm. J Exp Biol 200:883-896

Grieshaber MK, Hardewig I, Kreutzer U, Poertner HO (1994) Physiological and metabolic responses to hypoxia in invertebrates. Rev Physiol Biochem Pharmacol 125:43-147

Hand SC. Somero GN (1983) Energy metabolism pathways of hydrothermal vent animals: adaptations to a food-rich and sulfide-rich deep-sea environment. Biol Bull (Woods Hole) 165:167-181

Hentschel U, Felbeck $H$ (1993) Nitrate respiration in the hydrothermal vent tube worm Riftia pachyptila. Nature $366: 338-340$

Jannasch HW, Mottl MJ (1985) Geomicrobiology of deep-sea hydrothermal vents. Science 229:717-725

Johnson KS, Childress JJ, Beehler CL (1988a) Short term temperature variability in the Rose Garden hydrothermal field. Deep-Sea Res 35:1711-1722

Johnson ML, Childress JJ, Hessler RR, Sakamoto-Arnold CM, Beehler CL (1988b) Chemical and biological interactions in the Rose Garden hydrothermal vent field. Deep-Sea Res 35:1723-1744

Jones ML (1981a) Riftia pachyptila Jones: observations on the vestimentiferan worms from the Galapagos Rift. Science 213:333-336

Jones ML (1981b) Riftia pachyptila, new genus, new species, the vestimentiferan tube worm from the Galapagos Rift geothermal vents. Proc Biol Soc Wash 93:1295-1313

Kluytmans JH, Veenhof PR, de Zwaan A (1975) Anaerobic production of fatty acids in the sea mussel Mytilus edulis L. J Comp Physiol 104:71-78

Michal GH, Beutler HO, Lang G, Guenther U (1976) Enzymatic determination of succinic acid in food stuffs. Z Anal

Editorial responsibility: Otto Kinne (Editor),

Oldendorf/Luhe, Germany
Chem 279:137-138

Podesta RB, Mustafa T, Moon TW. Hulbert WC, Mettrick DF (1976) Anaerobes in an aerobic environment: role of $\mathrm{CO}_{2}$ in energy metabolism of Hymenolepis diminuta. In: van den Bosche $\mathrm{H}$ (ed) Biochemistry of parasites and hostparasite relationships. Elsevier, Amsterdam, p 81-94

Pospesel $: 1.4$, Hentschel $U$, Felbeck $H$ (in press) Determination of nitrate in the blood of the hydrothermal vent worm Riftia pachyptila using a bacterial nitrate reduction assay. Deep-Sea Res

Putzer V (1985) Der anaerobe Stoffwechsel des Glanzwurms Lumbriculus variegatus. Thesis, University of Innsbruck

Schiedek D (1997) Marenzelleria viridis (Verrill 1873) (Polychaeta) a new benthic species within European coastal waters. Some metabolic features. J Exp Mar Biol Ecol 211 $85-101$

Schiedek D, Schoettler U (1990) The energy production of juvenile Arenicola marina (Polychaeta) under anoxic and hypoxic conditions. Helgol Meeresunters 44:135-145

Schoettler U (1978) Investigations on the anaerobic metabolism of the polychaete worm Nereis diversicolor $M$ J Comp Physiol 125:185-189

Schoettler U, Bennett EM (1991) Annelids. In: Bryant C (ed) Metazoan life without oxygen. Chapman and Hall, London, p 165-185

Stewart V (1988) Nitrate respiration in relation to facultative metabolism in Enterobacteria. Microbiol Rev 52:190-232

Zebe E (1975) In-vivo Untersuchungen über den GlucoseAbbau bei Arenicola manna (Annelida, Polychaeta) J Comp Physiol 101:133-145

Zebe E, Salge U, Wiemann C, Wilps $\mathrm{H}$ (1981) The energy metabolism of the leech Hirudo medicinalis in anoxia and muscular work. J Exp Zool 218:157-163

Submitted: February 17, 1998; Accepted: August 5, 1998

Proofs received from author(s): November 4, 1998 